\title{
Winter pre-conditioning of seabird phenology in the California Current
}

\author{
Isaac D. Schroeder ${ }^{1,}{ }^{*}$, William J. Sydeman ${ }^{2,3}$, Nandita Sarkar ${ }^{1}$, \\ Sarah Ann Thompson ${ }^{2}$, Steven J. Bograd ${ }^{1}$, Franklin B. Schwing ${ }^{1}$ \\ ${ }^{1}$ NOAA, Southwest Fisheries Science Center, Environmental Research Division, 1352 Lighthouse Avenue, \\ Pacific Grove, California 93950-2097, USA \\ ${ }^{2}$ Farallon Institute for Advanced Ecosystem Research, PO Box 750756, Petaluma, California 94954, USA \\ ${ }^{3}$ Bodega Marine Laboratory, 2099 Westside Road, Bodega Bay, California 94923, USA
}

\begin{abstract}
Climate change is predicted to affect the phasing and amplitude of upwelling in eastern boundary current marine ecosystems. Effects may be strongest during the spring or summer 'upwelling season,' but may also be influential during winter before the spring transition. We tested the hypothesis that wintertime environmental forcing 'pre-conditions' the ecosystem and affects the timing and success of breeding in 2 species of seabird, Cassin's auklet Ptychoramphus aleuticus and common murre Uria aalge, reproducing in the central California Current. Time series of the mean and variance of egg-laying dates were correlated with regional winds and sea surface temperature, which were used as proxies for the forcing and oceanic response of coastal upwelling, respectively. Winter proxies of upwelling were the most significant determinants of seabird reproductive phenology, with anomalously strong upwelling in January to March leading to earlier dates of egg-laying in both species. We hypothesized that anomalous (early) winter upwelling, even of weak magnitude or short duration, could seed the region with sufficient nutrients to enhance productivity and prey availability, leading to a healthier adult breeding population and an earlier start to the breeding season. The magnitude of the previous year's November winds were also positively correlated with the variance of egg-laying dates for the common murre, with upwelling-favorable winds leading to greater synchrony in egg-laying. We conclude that winter environmental conditions are important determinants of ecosystem dynamics in the California Current, and that seabird phenology is a particularly useful ecosystem indicator.
\end{abstract}

KEY WORDS: Cassin's auklet · Common murre · California current · Phenology · Upwelling · Winter · Ecosystem indicator

Resale or republication not permitted without written consent of the publisher

\section{INTRODUCTION}

Global climate change is expected to alter both the mean and variance of many meteorological and oceanographic parameters (Trenberth 2001, IPCC 2007), including the phasing and intensity of upwelling in eastern boundary current marine ecosystems. Changes in the phasing of upwelling may influence habitat suitability, primary productivity, and various mid-level ecological interactions (Stenseth et al. 2002, Parmesan 2006), with ascending effects to the upper trophic levels. The effects of changes in upwelling on ecosystem dynamics may be greatest during the spring-summer upwelling season, but may also be influential during winter before the spring transition.

As an apparent consequence of climate change, a variety of plant and animal parameters, including life history characteristics and demographic attributes, have shifted in a manner consistent with expectations under global climate warming. However, the vast majority $(>90 \%$ ) of changes documented to date come from terrestrial ecosystems and species (Richardson \& Poloczanska 2008). Very few of these studies examined changes in biological time series, other than variability 
in the average parameter state, and whether mean values have shifted systematically through time. Phenology is defined as the timing of key events in plant or animal life histories, for example, the average dates of egg-laying in birds or bud burst in trees. Phenology is a very sensitive indicator of climate-driven ecosystem changes (Beebee 1995, Forchhammer et al. 1998, Stenseth \& Mysterud 2002, Parmesan \& Yohe 2003, Root et al. 2003, Parmesan 2006). In marine ecosystems, phenological changes have been related to climate variability and change for both lower (Mackas et al. 2001) and upper trophic level species (Abraham \& Sydeman 2004).

A substantial component of the climate change literature for marine ecosystems concerns marine birds (Durant et al. 2004). Studies from the northern and southern hemispheres have related seabird phenology to oceanographic and atmospheric variability (Sydeman et al. 1991, 2006, Bertram et al. 2001, Abraham \& Sydeman 2004, Frederiksen et al. 2004, Barbraud \& Weimerskirch 2006, Reed et al. 2006, 2009, Byrd et al. 2008, Wolf et al. 2009), but none of these studies examined anything other than mean or median dates of reproduction, and most studies have looked at 'oceanographic climate' during the spring/summer breeding periods for the birds. Indeed, investigating within-season variability in winter, spring, and summer, and in relation to the distribution of dates of reproduction and reproductive success may be revealing. Moreover, few studies, with the exception of Abraham \& Sydeman (2004), examined early oceanographic or climatic parameters that may 'pre-condition' ecosystems and influence the developing food webs upon which seabirds depend to obtain the resources for reproduction.

Seabirds have been proposed to be among the best environmental and ecological indicators for coastal marine ecosystems (Cairns 1987). Phenological attributes of seabirds are clearly relevant to evaluating the role of seabirds as indicators of marine ecosystem and food web dynamics. In particular, it has been argued that seabirds are reliable indicators because as top predators they 'integrate' and 'amplify' environmental variability to produce interpretable signals in their time series. This assumption has rarely been tested comprehensively (but see Wells et al. 2008).

In the present study, we evaluated the hypothesis that seabirds integrate environmental variability, and, as a result, demonstrate interpretable signals in their phenology that are significant in a climate changeecosystem change context. We tested this hypothesis by correlating wind and sea surface temperature (SST) time series over a wide geographic area with egglaying dates of 2 species of seabird in the California Current large marine ecosystem along the US west coast. Winds and SST were used as proxies for the forcing and oceanic response for coastal upwelling, respectively (Huyer 1983, Hickey 1998). We selected 2 species of birds, a planktivore (Cassin's auklet) and a piscivore (common murre), to examine differential responses to variation in the duration and phasing of upwelling. We investigated ecosystem pre-conditioning and how seabirds integrate environmental variation by considering how wind and SST influence phenology up to 6 to 8 mo before the initiation of reproduction each year.

\section{MATERIALS AND METHODS}

Egg laying data for Cassin's auklet Ptychoramphus aleuticus and common murre Uria aalge, herein referred to as auklet and murre, have been collected by biologists of the Point Reyes Bird Observatory (PRBO) under contract with the US Fish and Wildlife Service (USFWS) at Southeast Farallon Island (SEFI; $37^{\circ} 41^{\prime} 53.88^{\prime \prime} \mathrm{N}, 123^{\circ} 0^{\prime} 5.76^{\prime \prime} \mathrm{W}$; Fig. 1) since the early 1970s. The Farallon National Wildlife Refuge, including SEFI and the North Farallon Islands, hosts one of the richest marine bird nesting colonies in the world, with at least 12 regularly breeding species (Sydeman et al. 2001). Auklets are planktivorous, feeding primarily on euphausiid crustaceans (Ainley et al. 1996, Abraham \& Sydeman 2004, 2006) and have a foraging radius of $\sim 60 \mathrm{~km}$ from the colony (Mills et al. 2007); they do not generally forage on inner shelf habitats (<50 m depth; Yen et al. 2005). In contrast, murres are omnivores and generally range within the $3000 \mathrm{~m}$ isobath, and $\sim 100 \mathrm{~km}$ from the colony (Mills et al. 2007). Once murres finish molting they occupy nest sites on the Farallones in October and November (Ainley \& Boekelheide 1990). Auklets inhabit the Farallones throughout the year, but in September and October they tend to molt at sea (Manuwal 1974). Each year, a variable number of birds is profiled, and the dates when eggs are laid and hatched are recorded and fledgling survival is observed (see Appendix 1 for summary statistics on reproductive timing). For both species, only the first egg-laying dates are considered in the calculation of the mean and variance time series. Thus, we have a $35 \mathrm{yr}$ time series of the mean and variance of egg-laying dates for both auklets and murres. Hatching dates were not used, as the results were quantitatively similar to that of egg-laying dates, and we were most interested in the climate-oceanographic correlates of the initiation of breeding dates, which is best studied using egg-laying dates.

The environmental variables compared to the seabird phenology are based on satellite-derived SST and meridional wind data, available from the National Oceanic and Atmospheric Administration (NOAA) 


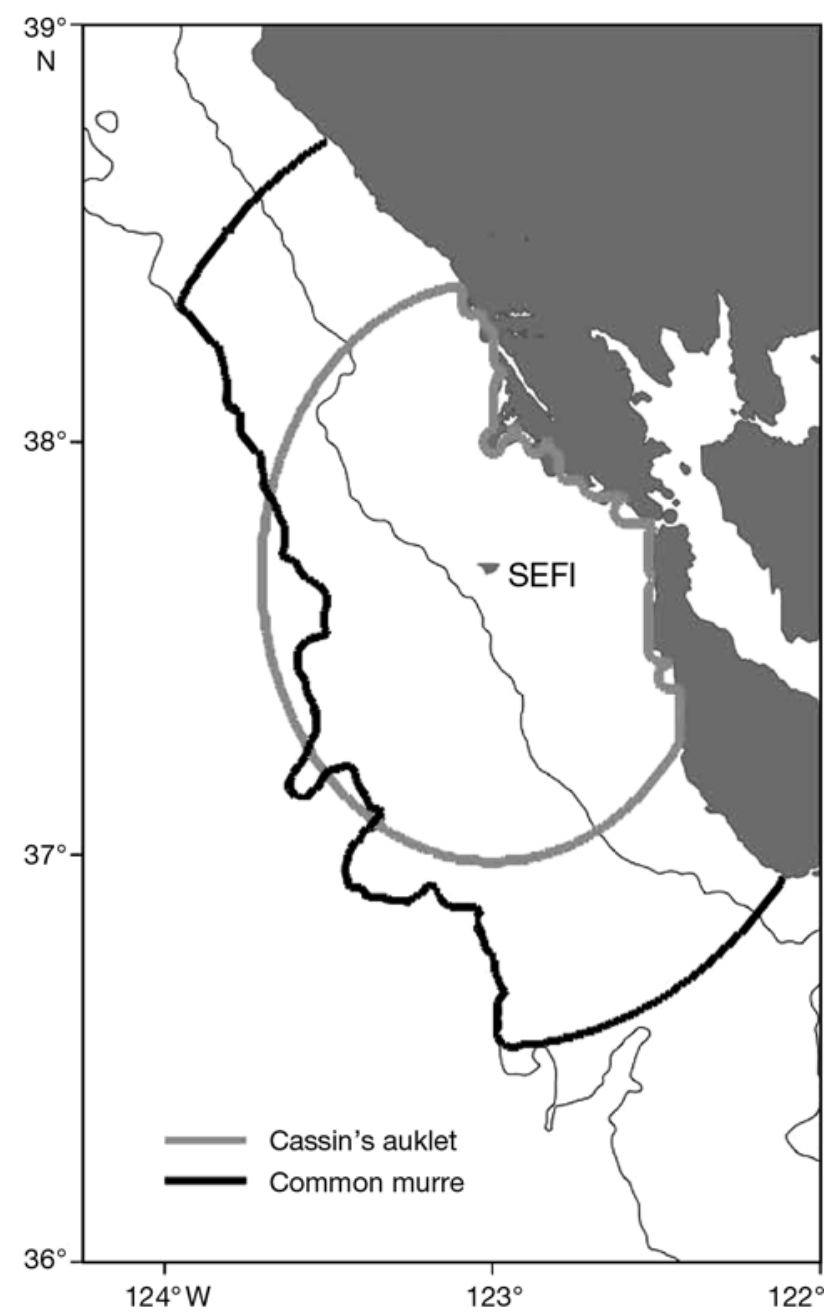

Fig. 1. Southeast Farallon Islands (SEFI), showing the estimated foraging ranges for common murre and Cassin's auklet. The $300 \mathrm{~m}$ and $3000 \mathrm{~m}$ isobath are contoured

Coastwatch Program (http://coastwatch.pfel.noaa.gov/ data.html). The SST data come from Pathfinder version 5.0 day and night monthly composites, available from January 1985 to the present at a spatial resolution of $4.4 \mathrm{~km}$ (Kilpatrick et al. 2001). The wind data are from NOAA/NCDC blended monthly mean sea surface winds at $0.25^{\circ}(\sim 25 \mathrm{~km})$ resolution (Zhang et al. 2006). The west coast of North America in the vicinity of the Farallon Islands is oriented in the north-south direction, thus the ' $\mathrm{v}$ ' component of the wind is aligned along the north-south (meridional) direction and drives coastal upwelling. Southward winds $(-v)$ are upwelling favorable, whereas northward winds (+v) cause downwelling.

Analyses have been performed over the time period common to the biological and physical time series (1988 to 2006). Gaps in the SST data were filled by a linear interpolation on the monthly mean time series at a particular grid location; for the months of January through March, only $8 \%$ of the total time series had $>3$ missing monthly values. Over $80 \%$ of the total time series had $<5$ missing months. Most gaps in the time series were only $1 \mathrm{mo}$ in length, but some were up to 5 mo, especially in the coastal area around Point Conception, California $\left(34.5^{\circ} \mathrm{N}, 121^{\circ} \mathrm{W}\right)$. There were no gaps in the meridional wind time series.

Statistical analyses. Spearman's rank correlation method (Kendall \& Gibbons 1990) was used to relate the physical and biological series, as this technique does not assume normal distributions for the time series. The method calculates a correlation coefficient, $\mathrm{C}$, and a probability, $\mathrm{p}$, that the correlation is due to chance. The relationship between any 2 time series may be simultaneous (lag 0 ), or one may lead or lag the other. We derived spatial correlation maps between the monthly mean gridded satellite data for a particular month (winds and SST) and the annual mean and variance of egg-laying dates for each species. To examine the cumulative effect of upwelling, averages of consecutive months were also considered. Only spatial correlation maps with large areas of significant correlations were used in the final interpretation of the birds' response to the physical oceanic conditions. Given the large number of tests performed, correlations with $\mathrm{p}<0.01$ were assumed to be significant.

\section{RESULTS}

\section{Variability in egg-laying dates}

The mean and variance of egg-laying dates for both auklets and murres were related to annual reproductive success (number of chicks fledged per breeding pair). For both species, egg-laying dates were inversely related to breeding success $(C=-0.33, p<0.06$ for auklets and $\mathrm{C}=-0.39, \mathrm{p}<0.02$ for murres). That is, an early mean egg-laying date resulted in a larger number of viable fledglings per breeding pair. However, the 2 species show different relationships between egg-laying variances and reproductive success, especially since $\sim 1990$. Auklets were lower in trophic level, generally breeding earlier in the year, and having more variability in timing of egg-laying than murres. For auklets, variance in egg-laying corresponding to a longer breeding season, with younger birds typically breeding later in the season; this could result in a positive relationship with breeding success if the birds raise more than 1 clutch ('double-brood') in years of extended reproduction (Abraham \& Sydeman 2004). In contrast, reproductive success of murres was enhanced when breeding synchrony was greatest (Birkhead 1977, Sydeman et al. 1991), with synchrony re- 
flected by small variance in egg-laying dates $(\mathrm{C}=$ $-0.51 ; \mathrm{p}<0.01)$.

The mean egg-laying dates for auklets and murres between 1972 and 2006 reveal substantial interannual variability (Fig. 2a). From 1972 to 2006, there was a positive trend in the auklet mean egg-laying dates (slope $=0.40 \mathrm{~d} \mathrm{yr}^{-1}, \mathrm{p}=0.14$ ) and a negative trend in the murre mean egg-laying dates (slope $=-0.24 \mathrm{~d} \mathrm{yr}^{-1}$, $\mathrm{p}=.07$ ). The planktivorous auklets initiated reproduction before murres in all years except 1992. In strong El Niño years $(1983,1992,1998)$, the mean egg-laying dates for both species were significantly delayed; for auklets, the delay was upwards of $60 \mathrm{~d}$, whereas for murres it was $\sim 20 \mathrm{~d}$. The mean egg-laying dates of the species were correlated $(\mathrm{C}=0.55, \mathrm{p}<0.01)$. The variance in egg-laying dates (Fig. 2b) changed over the observation period. Until 1990, the variances of egglaying dates for both species co-varied $(\mathrm{C}=0.46, \mathrm{p}<$ 0.05), but the correlation was negative $(\mathrm{C}=-0.51, \mathrm{p}<$ 0.05) after 1990. During El Niño years, variance in egglaying dates of auklets decreased, whereas for murres the variance increased. The mean and variance of egglaying dates for auklets were inversely correlated $(\mathrm{C}=$ $-0.47, \mathrm{p}<0.01$ ) - when breeding early the population showed greater variability. For murres, there was no meaningful correlation between the mean and variance.

\section{Correlation maps between meridional winds and egg-laying dates}

Correlation maps constructed from correlations between meridional winds and mean egg-laying dates showed significant correlations only for the months of January, February, and January-February combined (other months are not shown). The correlations were positive and hold for both auklets (Fig. 3a) and murres (Fig. 3b), indicating that wintertime upwelling-favorable winds correspond to earlier mean egg-laying dates for both species. The January correlations for both species ranged between 0.58 and 0.76 for most of the region between $32^{\circ}-44^{\circ} \mathrm{N}$ and $120^{\circ}-128^{\circ} \mathrm{W}$, encompassing almost the entire US West Coast. For auklets, the spatial correlations break down north of $41^{\circ} \mathrm{N}$ and in the area south of $36^{\circ} \mathrm{N}$, shoreward of $123^{\circ} \mathrm{W}$. For murres, the correlations break down primarily in the southern part of the domain. In February, the regions of high correlation for both auklets and murres lie south of the Farallon Islands, having values between 0.58 and 0.70 .

The correlation map with the largest area of significant correlations was for the time series constructed by averaging the January and February meridional winds. The spatial extent of the correlation was similar for both auklets and murres, with high correla-
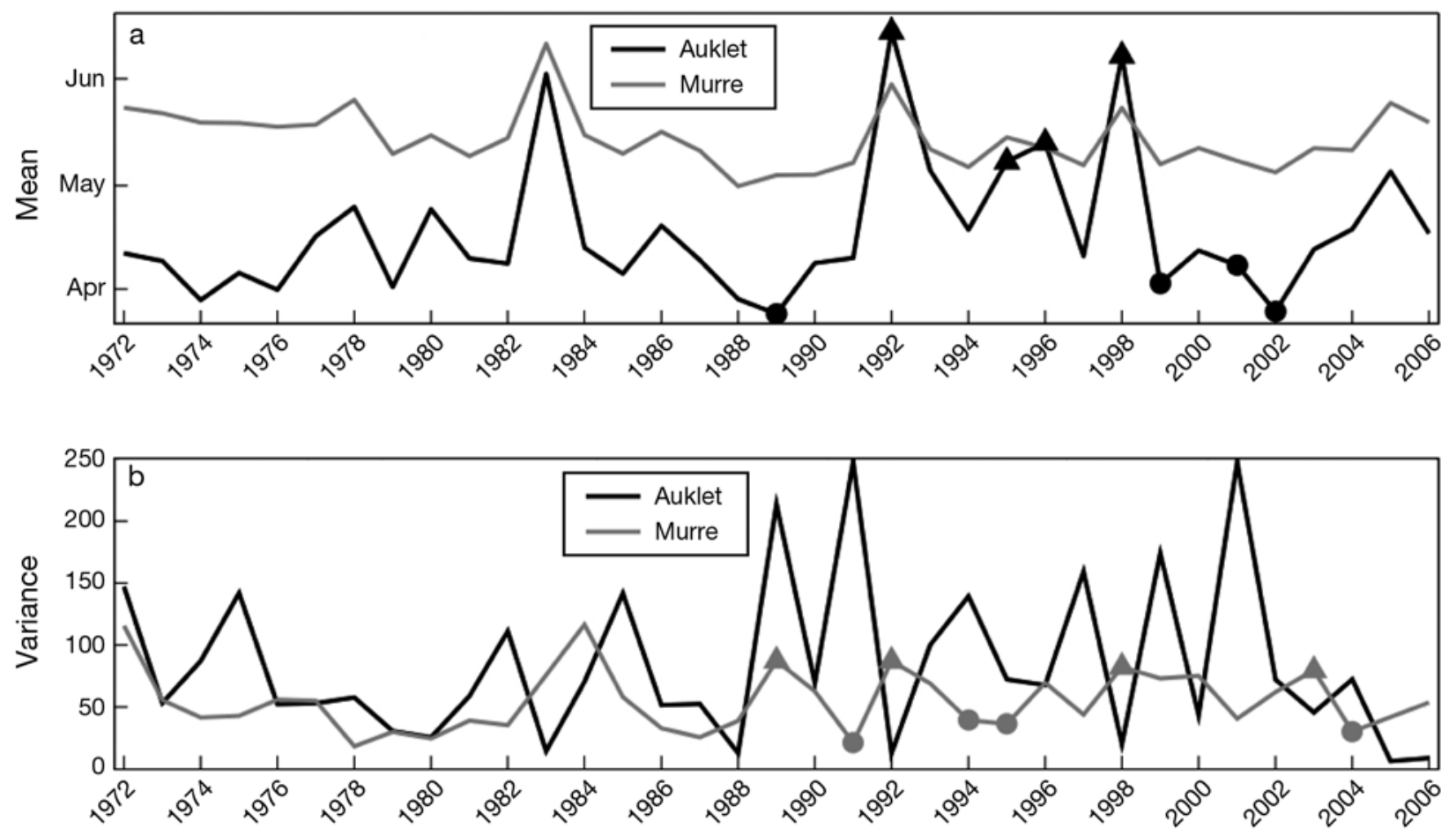

Fig. 2. Ptychoramphus aleuticus and Uria aalge. Time series of (a) mean of egg-laying dates and (b) variances of egg-laying dates. For the time period 1988 to 2006 (years of available wind and sea surface temperature (SST) data), the 4 years of the smallest (largest) values of auklet means and murre variances are marked with circles (triangles) 

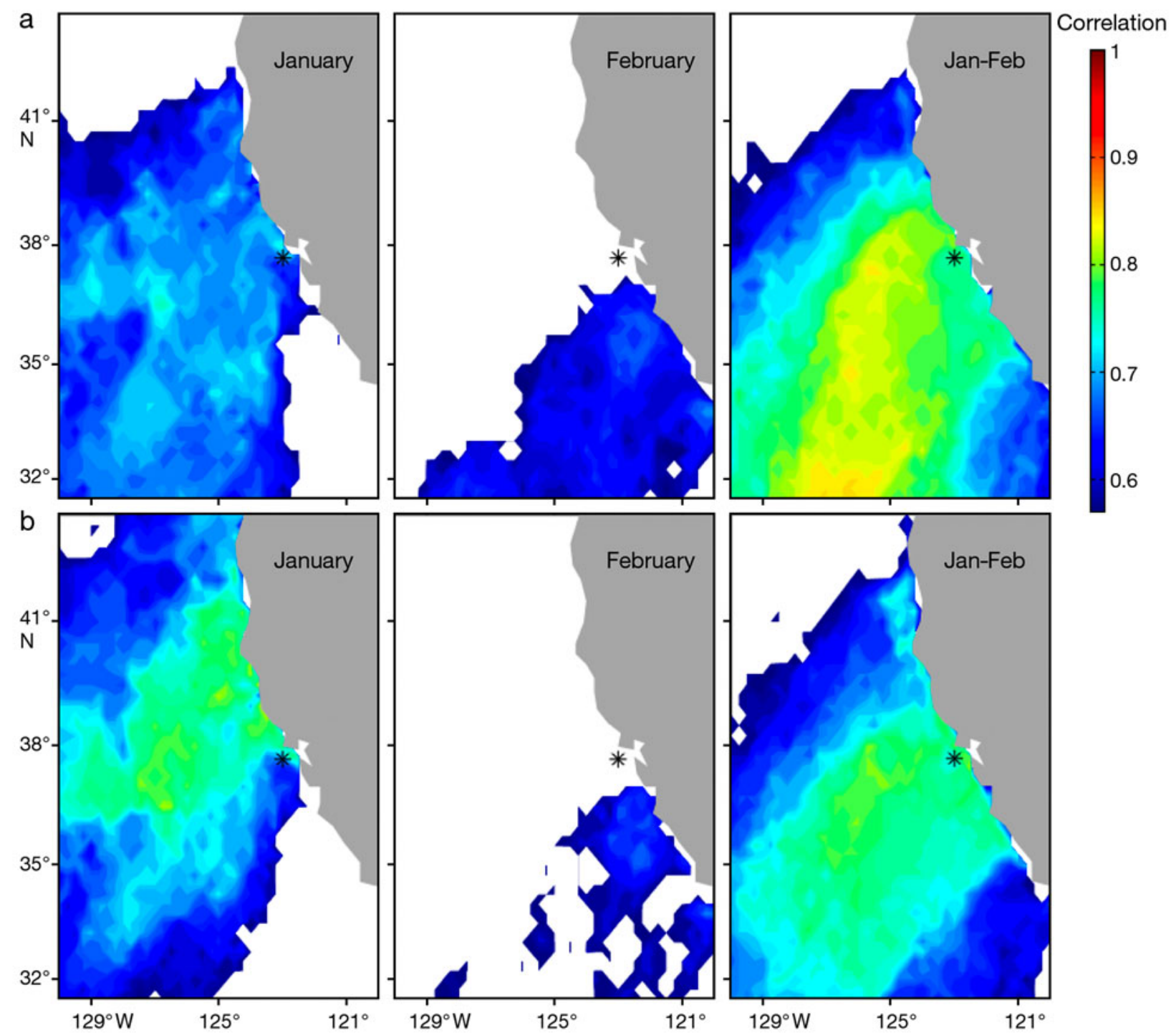

Fig. 3. Ptychoramphus aleuticus and Uria aalge. Correlations between meridional wind and mean egg-laying dates for (a) auklets and (b) murres. The spatial meridional wind data are the monthly means for January, February, and the average of January and February. For this and all subsequent correlation maps, a black asterisk marks the location of southeast Farallon Islands (SEFI). Only correlations with $\mathrm{p}<0.01$ are shown; areas in white are for non-significant correlations $(\mathrm{p}>0.01)$

tions throughout the domain, except for an increasing area of low or non-significant correlations north of approximately $40^{\circ} \mathrm{N}$. It is interesting to note that while correlation values were highest for auklets in the composite of January-February winds, the January winds alone provided the highest correlations for murres. The relationships for both species are slightly non-linear; a quadratic regression of wintertime January-February winds explained $60.61 \%$ of the variance in mean egg-laying dates of auklets (Fig. 4a) and $44.87 \%$ of the variance in egg-laying dates of murres (Fig. 4b).

A strong positive relationship occured between meridional winds and variance of murre egg-laying dates
(Fig. 5), but no such relationship existed for auklets. A positive correlation indicates that northward (downwelling favorable) winds are related to higher variance in murre egg-laying dates. Notably, the correlation was strongest in November of the previous year (e.g. the 1983 egg-laying variance was correlated to the November 1982 meridional winds), with a maximum correlation value of $\mathrm{C}=0.94$, centered at $42^{\circ} \mathrm{N}, 132^{\circ} \mathrm{W}$, which decreases offshore to $\mathrm{C}=0.59$. This region of high positive correlation is located well to the northwest of the Farallon Islands, but corresponds to the center of the North Pacific (subtropical) High, which modulates coastal upwelling in the California Current (Schwing et al. 2002). 


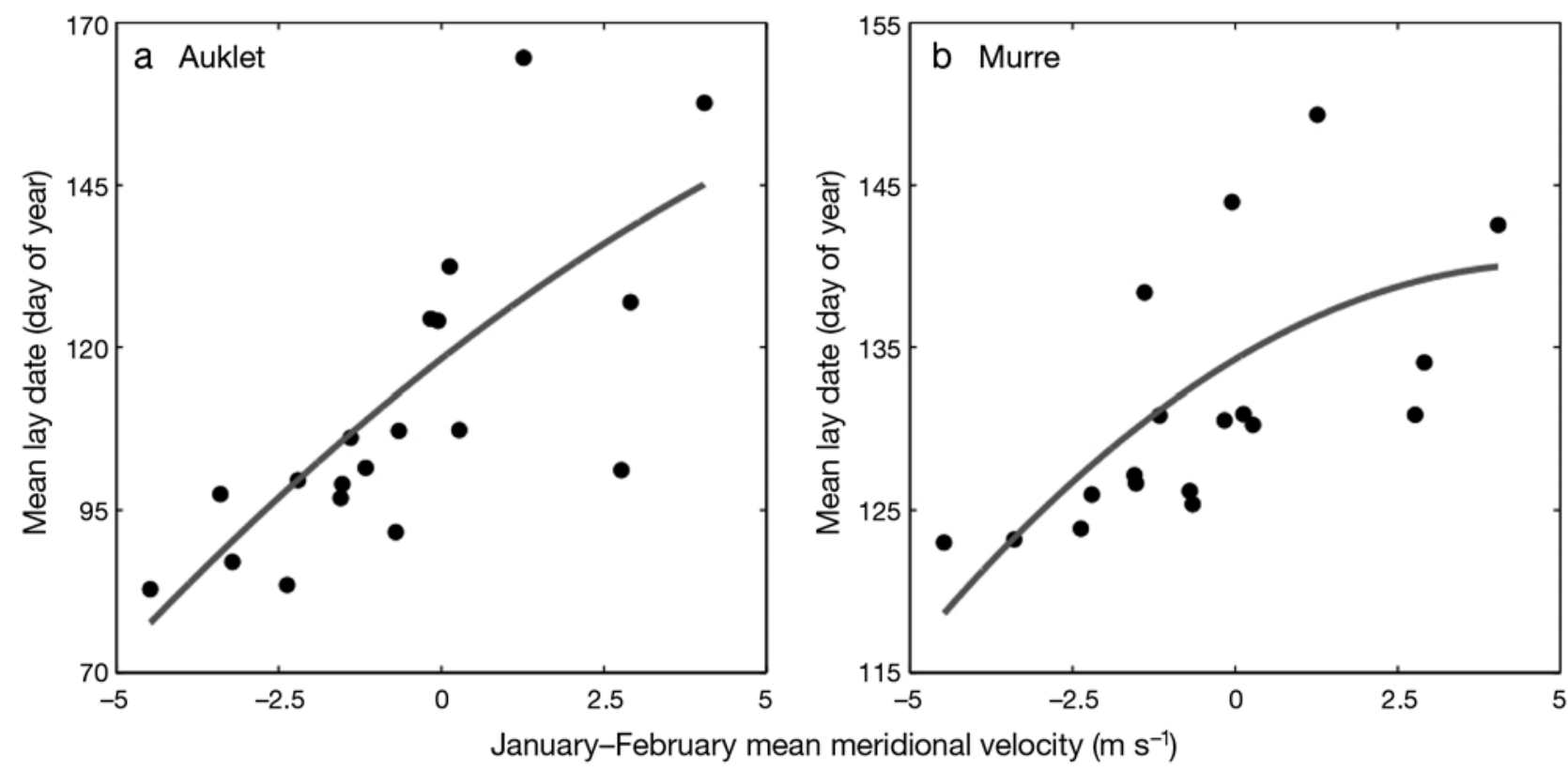

Fig. 4. Ptychoramphus aleuticus and Uria aalge. Bivariate plot between meridional wind and mean egg-laying dates for (a) auklet and (b) murre. Location of the January-February mean meridional wind data is $37.5^{\circ} \mathrm{N}, 125.5^{\circ} \mathrm{W}$

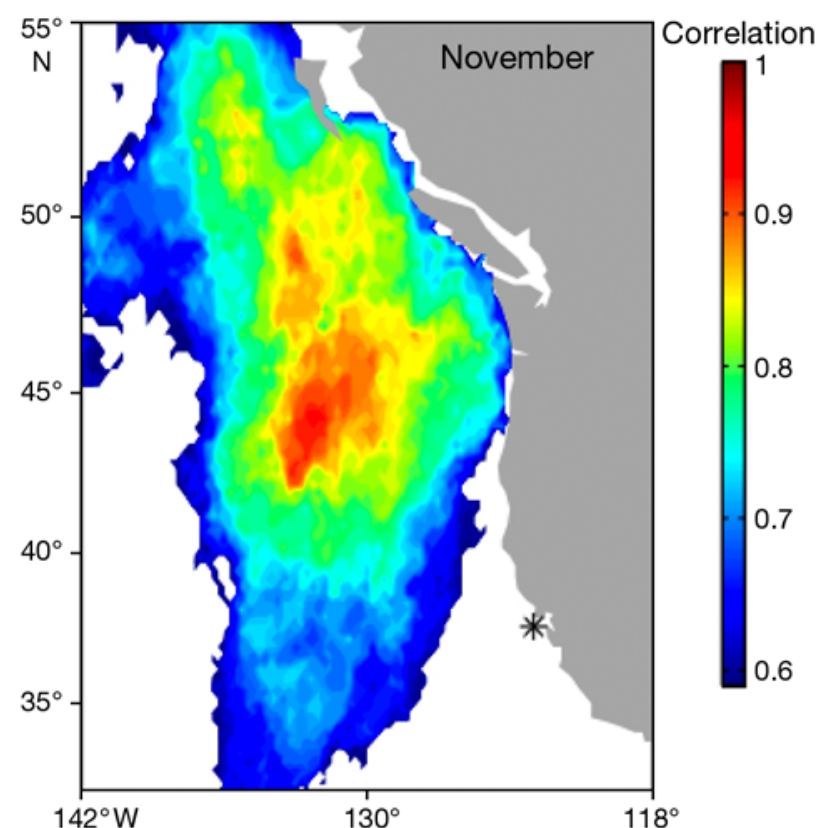

Fig. 5. Uria aalge. Correlations between meridional winds and variances of egg-laying dates for murres. Wind data are monthly means for November of the previous year

\section{Correlation between SST and egg-laying dates}

Correlation maps of SST and mean egg-laying dates for February, March, and February-March showed the greatest extent of significant positive correlations for both auklets (Fig. 6a) and murres (Fig. 6b). Positive correlations imply that both species lay their eggs earlier (later) when the regional SST is cool (warm). The correlation maps of SST have a much higher spatial resolution $(4.4 \mathrm{~km})$ than the wind correlation maps (approximately $25 \mathrm{~km}$ ), and consequently appear grainier. Both auklets and murres had similar spatial correlation patterns, with higher correlations along the coast and decreasing correlations with increasing distance offshore. However, the offshore extent, as well as the magnitude, of the correlation coefficients was much higher for auklets than murres in all 3 temporal averages (February, March, and February-March).

In February, auklet correlation values were highest ( $\mathrm{C}=0.94)$ southward of the Farallon Islands, on the continental shelf. In March, the area of highest correlation $(\mathrm{C}=0.97)$ was in the northern shelf area, around $42^{\circ} \mathrm{N}$. The SST averaged over February and March had the highest spatial extent of significant correlation. The same spatial patterns were evident in the murreSST correlation maps, though with generally lower correlations everywhere.

There were also significant correlations between SST and the variance of auklet egg-laying dates in February (Fig. 7). These correlations were negative, ranging from -0.79 to -0.58 , implying that colder SSTs are associated with longer time spans of egg-laying periods. However, the spatial extent of the significant correlations was rather limited. No significant correlations were found between SST time series and variance of murre egg-laying dates. 

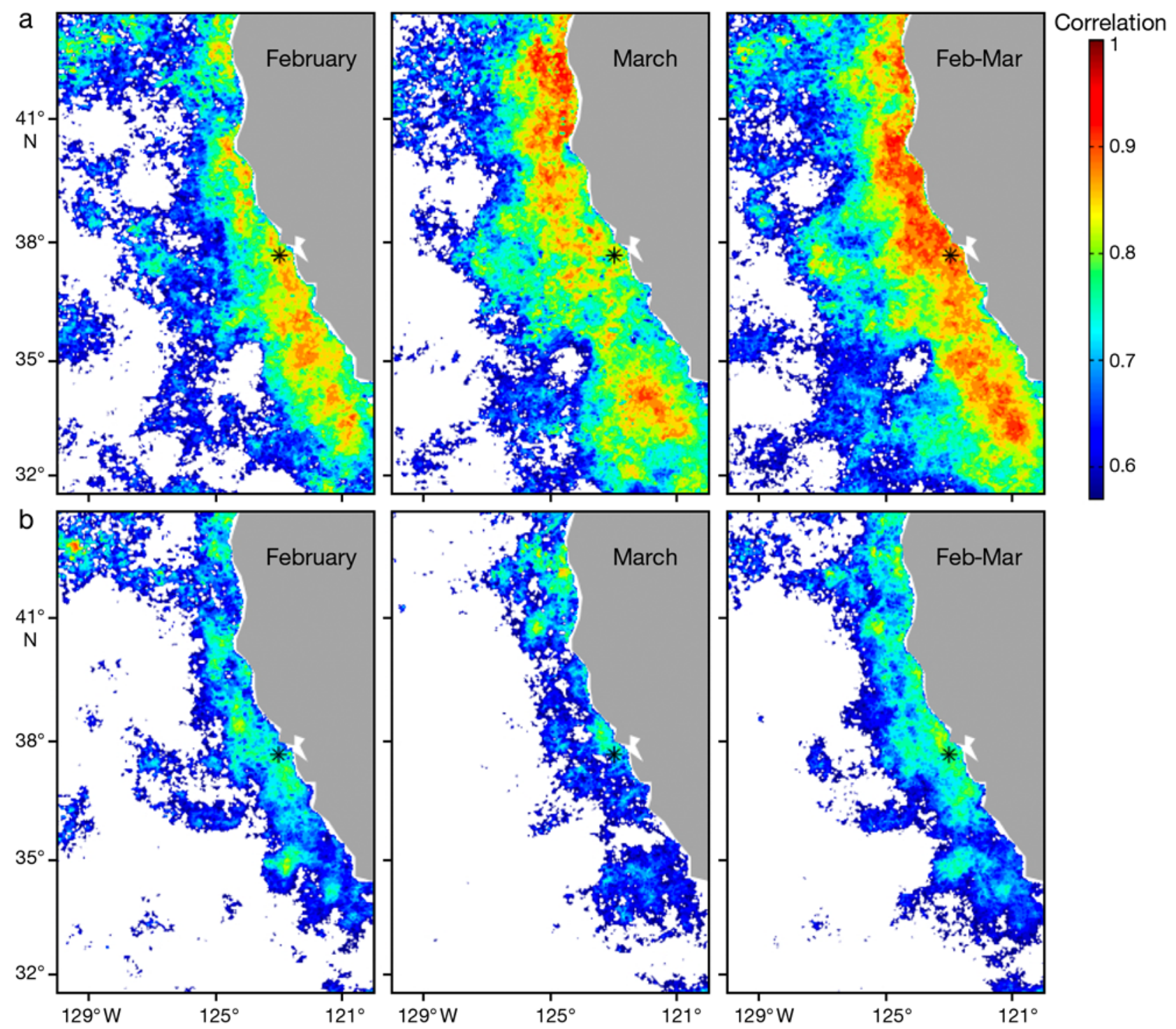

Fig. 6. Ptychoramphus aleuticus and Uria aalge. Correlations between sea surface temperature (SST) and mean egg-laying dates for (a) auklets and (b) murres. SST data are monthly means for February, March, and the average of February and March

\section{DISCUSSION}

We have evaluated the hypotheses that wintertime environmental forcing 'pre-conditions' the ecosystem and that seabirds 'integrate' environmental variability as demonstrated by interpretable signals in their timing of breeding (i.e. phenology). We tested these hypotheses by creating monthly estimates of winds and SSTs over the Northeast Pacific and producing spatial correlation maps to investigate the overall scales of integration. Upwelling in the central-northern California Current is most intense during the months of May to July each year (Bograd et al. 2009), but we found wintertime (November, January to March) proxies of up- welling to be the most significant determinants of seabird phenology. Upwelling in the California Current is the primary driver for primary and secondary productivity (Largier et al. 2006), so undoubtedly the relationships we have established are indirect, mediated by changes in prey resource availability. Herein, we compare the responses of these 2 species of seabird, an obligate planktivore (auklet) and an omnivore (murre), to winter environmental conditions, as indexed by surface winds (atmospheric forcing) and SSTs (oceanic response). We touch upon the specifics of prey resource availability later in this discussion. To our knowledge, this is one of the first attempts at a spatio-temporal integration of climate-oceanographic and 


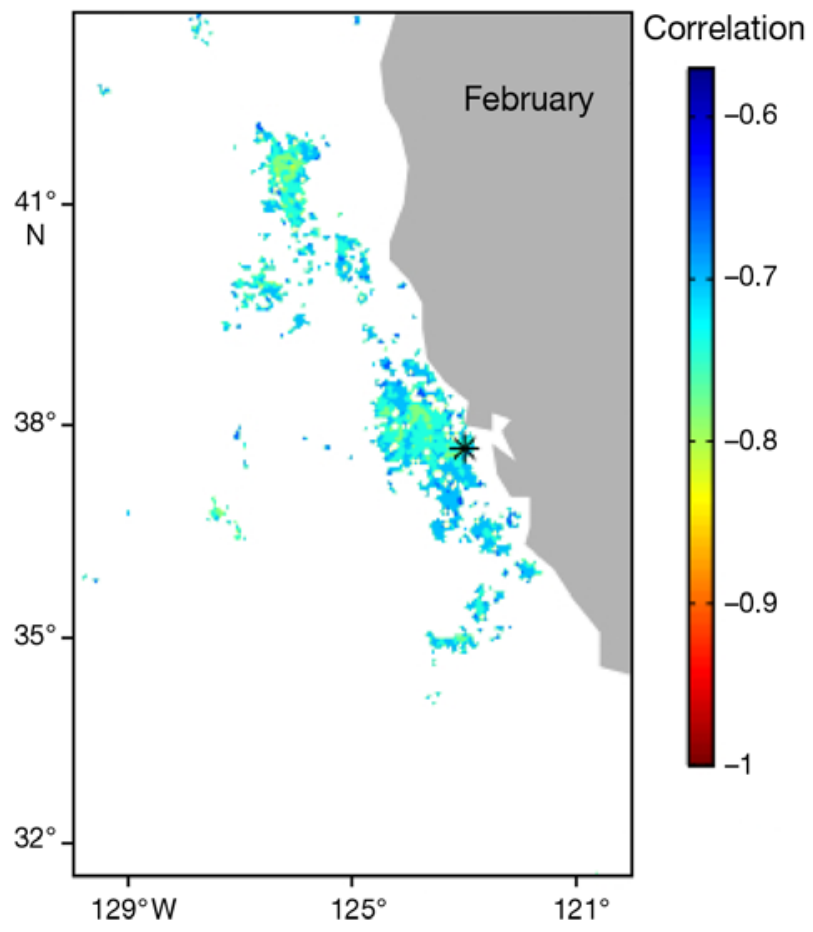

Fig. 7. Ptychoramphus aleuticus. Correlations between sea surface temperature (SST) and variances of egg-laying dates

for auklets. SST data are monthly means for February phenological variables. Clearly such information is critical to assessing the role of seabird phenology as an indicator of ecosystem dynamics, as has been recently proposed (Sydeman et al. 2008).

\section{Ecosystem pre-conditioning}

Previous studies have found relationships between wintertime oceanographic conditions and seabird ecology in the region (Abraham \& Sydeman 2004, Miller \& Sydeman 2004), but the temporal pattern of ecosystem 'pre-conditioning' revealed by the present study is considerably earlier than expected. The cumulative effect of meridional winds on the mean egg-laying dates for both species was strongest in winter (January and February). The spatial correlation maps revealed the strongest correlations to the north and southwest of the Farallones, presumably reflective of atmospheric forcing conducive to upwelling (Fig. 3). From an ornithological perspective, auklets and murres can produce eggs within $\sim 10$ to $15 \mathrm{~d}$ after fertilization (Astheimer 1986). The fast egg production and the spring timing of the average egg-laying (29 March to 7 May for auklets and 6 to 22 May for murres; Fig. 2a; Appendix 1) would suggest March/April environmen-
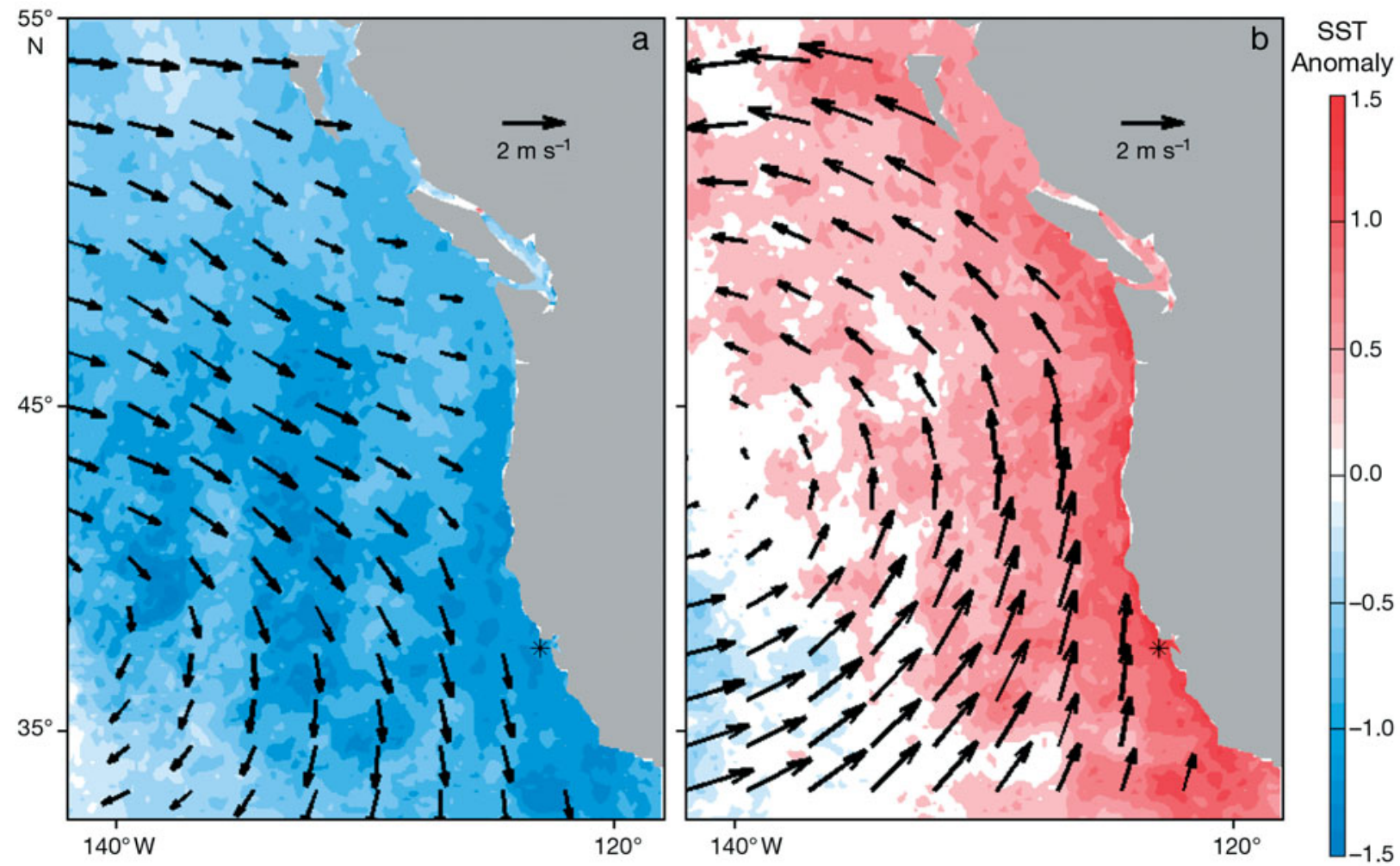

Fig. 8. Ptychoramphus aleuticus. Anomalies of January-February winds and February-March sea surface temperatures (SSTs) for (a) the 4 years of the earliest auklet egg-laying means and (b) mean of the 4 years of latest auklet egg-laying means. For clarity, arrows are plotted every $2.5^{\circ}$ 
tal signals being the most influential to the timing of breeding. However, from an ecosystem and food web development perspective, the winter relationships make sense. In the Point Arena region, upwelling is strongly intermittent in winter (Bograd et al. 2009). However, it is this intermittent upwelling that appears most significant to the timing of seabird egg-laying.

We hypothesize that intermittent upwelling in winter stimulates and fuels food web development, which ultimately affects seabird body condition and egg-laying dates. Estimates of the timing between upwelling and primary and secondary productivity are important in this regard. In the California Current system near Bodega Bay, upwelling followed by a relaxation of 3 to $7 \mathrm{~d}$ is most favorable for phytoplankton blooms (primary productivity; Wilkerson et al. 2006). For secondary production, the results are highly species dependent and also variable by year. Timing of seabird breeding is known to be influenced by the nutritional status of egg-laying females (Perrins 1970). Farallon auklets feed mostly on euphausiid crustaceans ('krill'). Coastal communities of Euphausia pacifica were comprised only of larval forms in January (Dorman et al. 2005). Our results show that upwelling during January and February is important to egg-laying of auklets and murres; therefore, it may be significant for the growth of krill as well. The prey of murres during the breeding season consists mainly of pacific hake, northern anchovy, and juvenile rockfish (Mills et al. 2007, Roth et al. 2008). Pacific hake spawn from January through March offshore of southern California, and juveniles and adults migrate northward to central California in the spring (Ressler et al. 2007, Agostini et al. 2008). Northern anchovy spawn year round, but late winter and early spring are peak spawning times (Parrish et al. 1986). Also, January through March is a very active period of fertilization/ parturition for some species of rockfish in the California Current (Eschevarria \& Lenarz 1984). Reed et al. (2009) used estimates of juvenile rockfish to show a relationship with murre phenology, although the forage fish data were obtained in May to June, after the egg-laying period of murres. Unfortunately, we lack data on the seasonal variation in food web components to estimate all the time lags involved. However, other studies on Farallon seabird phenology (Abraham \& Sydeman 2004, Reed et al. 2009, Wolf et al. 2009) and seabird phenology elsewhere in the world (Frederiksen et al. 2004, Barbraud \& Weimerskirch 2006, Reed et al. 2006, Byrd et al. 2008) have inferred, rather than demonstrated, that environmental relationships are due to variation in prey resources. In short, it seems that wintertime upwelling 'pre-conditions' the system and is important to the growth and development of many prey species that are likely related to the foraging success, body condition, and timing of breeding for these seabirds.

The seasonal cycle of water column structure in the California Current affects the biological utility of coastal upwelling. Surface stratification of the ocean off central-northern California is weakest in winter (Pennington \& Chavez 2000, Palacios et al. 2004) and calculation of Brunt-Väisälä frequencies showed the lowest values in January-February at the M2 mooring located near Monterey Bay (data not shown). Thus the upwelling of nutrient-rich water in winter could occur with winds that are weaker or of shorter duration than the winds that would be required for significant nutrient-favorable upwelling later in the season. Thus anomalous (i.e. early) winter upwelling, even of weak magnitude or short duration, could seed the region with sufficient nutrients to enhance productivity and prey availability. This 'pre-conditioning' of the system would allow for a healthier adult breeding population, hence an earlier start to the breeding season.

To further illustrate these results, we have summarized wind patterns and SST for the 4 earliest (1989, 2002, 1999, 2001) and 4 latest (1995, 1996, 1998, 1992) years for auklet egg-laying (Fig. 2a). January-February meridional winds and February-March SSTs for these early/late years were averaged and then subtracted from the climatological means to form anomaly maps representing conditions that are favorable or unfavorable for early egg-laying. The anomalous wind patterns for the early egg-laying years correspond to an anomalously strong Subtropical High pressure system, resulting in anticyclonic wind anomalies and stronger coastal upwelling. The corresponding February-March SST anomalies over the region are cooler than the climatology by up to $1.5^{\circ} \mathrm{C}$ (Fig. 8a). In contrast, the January-February anomaly winds for the 4 latest years of auklet egg-laying show strongly downwelling favorable conditions along the entire coast, and February-March SST anomalies warmer by up to $1.5^{\circ} \mathrm{C}$ (Fig. $8 \mathrm{~b}$ ).

\section{Within-season patterns: variance}

Measures of central tendency (mean and/or median) and variance structures are often correlated as they are here (to some extent), but variance as a parameter provides a novel view of phenology. From a breeding success perspective, greater variance for auklets does not necessarily lead to better reproduction, but less variance for murres results in better reproductive output. We found that November winds of the previous year were related to murre variance in egg-laying dates, but we found no relationships for auklets. We do not understand why this difference exists between the species, 
although we assume November winds only have an effect on the prey of murres. Moreover, we found that murre and auklet variances were positively correlated before 1990 and negatively correlated thereafter. As noted in the 'Results', we surmise that greater variance for auklets and less variance for murres is a positive response to favorable environmental conditions, which means that it is the positive correlation between auklet and murre variance prior to 1990 that requires explanation. While we do not fully understand this relationship, before 1990 murre egg-laying dates advanced significantly (Sydeman 1999, Reed et al. 2009), and perhaps this change in overall breeding date was related to a change in the variance structure of the data. For auklets, the number of years with high variances $(>150)$ only occurred after 1989, whereas there is no such shift to higher variances for the murres (Fig. 2b).

To illustrate the relationship between murre variance in egg-laying and environmental conditions, we applied the same process of looking at the average of the anomalous winds and SSTs for the $4 \mathrm{yr}$ of smallest and largest variances. The $4 \mathrm{yr}$ with the lowest variances are 1999, 2004, 1995, and 1994; the $4 \mathrm{yr}$ with the highest variances are 2003, 1998, 1992, and 1989 (Fig. 2b). The wind and SST patterns associated with the largest/smallest variance years are very similar to those for the earliest/latest auklet egg-laying years (Fig. 8); because of the similarity the figure is not shown. Years with the smallest variances have anticyclonic November wind anomalies. The wind magnitudes are very large north of $45^{\circ} \mathrm{N}$, with anomalies exceeding $4 \mathrm{~m} \mathrm{~s}^{-1}$ and directed from the northwest. The SST anomalies are cooler than the climatological mean over most of the region, with values between -0.5 to $-1{ }^{\circ} \mathrm{C}$ in the areas adjacent and to the north of the Farallones. The conditions for the highest variances are cyclonic wind anomalies; the SST anomalies over most of the region are warmer than the climatology. December SST anomalies of over $1.5^{\circ} \mathrm{C}$ are located just north of $45^{\circ} \mathrm{N}$, with upwelling conditions around the Farallones with wind magnitudes $\sim 1 \mathrm{~m} \mathrm{~s}^{-1}$ and SST anomalies of $\sim 0.5^{\circ} \mathrm{C}$.

\section{Seabird phenology as an ecosystem indicator}

Seabird phenology appears to be reflective of processes that determine ecosystem dynamics 3 to 5 mo prior to egg-laying for these species. Further refinements in understanding the mechanisms of the response are necessary, but we have a reasonable operational hypothesis, and have calibrated some of the functional relationships. Therefore, it seems appropriate to suggest seabird phenology as an indicator of wintertime ecosystem dynamics. Unlike for fish and other species in the system, the breeding timing of seabirds is relatively easy and inexpensive to measure. Indeed, it is hard to envision other taxa that could provide phenological indices of ecosystem dynamics early in each year. These indices could be extremely important in assessing ecosystem 'health' and resilience, and could be useful in a predictive context (Sydeman et al. 2008). Seabird phenology could provide a biological 'spring transition' index, which may be more meaningful to other biological organisms than a physically based index, such as changes in SST or sea level. Coupling both physical and biological indices of timing may be particularly useful for understanding ecosystem productivity.

\section{CONCLUSIONS}

Based on this investigation, we conclude that wintertime conditions are important determinants of ecosystem dynamics in the California Current and that future ecosystem studies should focus on physical forcing prior to the 'spring transition.' In some cases, the 'spring transition' may have been over-emphasized, when it is actually atmospheric-oceanographic interactions before the transition can be observed that are most significant to ecosystem productivity. The widespread correlations of winds and SST in January and February, and as early as November in the preceding year, support the notion that wintertime 'pre-conditioning' of the system is important. We have suggested that winds during periods of weak stratification may be mechanistically related to effectual upwelling in the system during winter, but this is certainly an area for future research.

Acknowledgements. This paper was first presented at the Topic Session on 'Phenology and climate change in the North Pacific: Implications of variability in the timing of zooplankton production to fish, seabirds, marine mammals and fisheries (humans)' on 2 November 2007 at the 16th Annual Meeting of PICES in Victoria, Canada. Data collected and maintained by PRBO in collaboration with the USFWS are available; for updated information contact J. Jahncke (jjahncke@prbo.org) and/or R. Bradley (rbradley@prbo.org). We thank PRBO and USFWS for data contributions to this project. The wind data were acquired from NOAA's National Climatic Data Center, via their website www.ncdc.noaa.gov/oa/rsad/blendedseawinds.html. The SST Pathfinder version 5.0 SST data set was produced by NOAA I NESDIS I NODC and the University of Miami. Funding for this analysis and write-up was provided by NOAA's Fisheries and the Environment (FATE) program and the California Ocean Protection Council and California Sea Grant under grant R/OPCENV-07 entitled 'Tackling Climate Change and Ecological Complexity: Matches and Mismatches in the Seasonal Cycle of California's Marine Flora and Fauna'. This is Farallon Institute contribution no. 002, and contribution no. 2467 of the Bodega Marine Laboratory. 


\section{LITERATURE CITED}

Abraham CL, Sydeman WJ (2004) Ocean climate, euphausiids and auklet nesting: inter-annual trends and variation in phenology, diet and growth of a planktivorous seabird, Ptychoramphus aleuticus. Mar Ecol Prog Ser 274:235-250

> Abraham CL, Sydeman WJ (2006) Prey-switching by Cassin's auklet Ptychoramphus aleuticus reveals seasonal climaterelated cycles of Euphausia pacifica and Thysanoessa spinifera. Mar Ecol Prog Ser 313:271-283

Agostini V, Hendrix A, Hollowed A, Wilson C, Pierce S, Francis R (2008) Climate-ocean variability and Pacific hake: a geostatistical modeling approach. J Mar Syst 71:237-248

Ainley DG, Boekelheide RJ (1990) Seabirds of the Farallon Islands. Stanford University Press, Palo Alto, CA

> Ainley D, Spear L, Allen S (1996) Variation in the diet of Cassin's auklet reveals spatial, seasonal, and decadal occurrence patterns of euphausiids off California, USA. Mar Ecol Prog Ser 137:1-10

Astheimer LB (1986) Egg formation in Cassin's Auklet. Auk 103:682-693

Barbraud C, Weimerskirch H (2006) Antarctic birds breed later in response to climate change. Proc Natl Acad Sci USA 103:6248-6251

Beebee TJC (1995) Amphibian breeding and climate. Nature 374:219-220

Bertram D, Mackas DL, McKinnell S (2001) The seasonal cycle revisited; interannual variation and ecosystem consequences. Prog Oceanogr 49:283-307

Birkhead T (1977) The effect of habitat and density on breeding success in the common guillemot. J Anim Ecol 46:751-764

> Bograd S, Schroeder I, Sarkar N, Qiu X, Sydeman WJ, Schwing F (2009) Phenology of coastal upwelling in the California Current. Geophys Res Lett 36:L01602, doi:10. 1029/2008GL035933

Byrd GV, Sydeman WJ, Renner HM, Minobe S (2008) Responses of piscivorous seabirds at the Pribilof Islands to ocean climate. Deep-Sea Res II 55:1856-1867

Cairns DK (1987) Seabirds as indicators of marine food supplies. Biol Oceanogr 5:261-271

> Dorman JG, Bollens SM, Slaughter AM (2005) Population biology of euphausiids off northern California and effects of short time-scale wind events on Euphausia pacifica. Mar Ecol Prog Ser 288:183-198

> Durant JM, Anker-Nilssen T, Hjermann DO, Stenseth NC (2004) Regime shifts in the breeding of an Atlantic puffin population. Ecol Lett 7:388-394

Eschevarria T, Lenarz W (1984) Conversions between total, fork and standard lengths in 35 species of Sebastes from California. Fish Bull (Wash DC) 82:249-251

Forchhammer MC, Post E, Strenseth NC (1998) Breeding phenology and climate? Nature 391:29-30

Frederiksen M, Wanless S, Harris MP, Rothery P, Wilson LJ (2004) The role of industrial fisheries and oceanographic change in the decline of North Sea black-legged kittiwakes. J Appl Ecol 41:1129-1139

Hickey BM (1998) Coastal oceanography of western North America from the tip of Baja California to Vancouver Island, Vol 11. Wiley and Sons, New York

Huyer A (1983) Coastal upwelling in the California Current System. Prog Oceanogr 12:259-284

IPCC (Intergovernmental Panel on Climate Change) (2007) Climate change 2007: the physical science basis. In: Solomon S, Qin D, Manning M, Chen Z and others (eds) Contribution of Working Group I to the Fourth Assessment, IPCC, Cambridge University Press, Cambridge and New York, NY
Kendall M, Gibbons JD (1990) Rank correlation methods. Edward Arnold, New York

Kilpatrick KA, Podesta GP, Evans G (2001) Overview of the NOAA/NASA advanced very high resolution radiometer Pathfinder algorithm for sea surface temperature and associated matchup database. J Geophys Res 106:9179-9197

> Largier JL, Lawrence CA, Roughan M, Kaplan DM and others (2006) WEST: A northern California study of the role of wind-driven transport in the productivity of coastal plankton communities. Deep-Sea Res II 53:2833-2849

> Mackas DL, Thomson RE, Galbraith M (2001) Changes in the zooplankton community of the British Columbia continental margin, 1985-1999, and their covariation with oceanographic conditions. Can J Fish Aquat Sci 58:685-702

> Manuwal DA (1974) The natural history of Cassin's Auklet (Ptychoramphus aleuticus). Condor 76:421-431

Miller AK, Sydeman WJ (2004) Rockfish response to low-frequency ocean climate change as revealed by the diet of a marine bird over multiple time scales. Mar Ecol Prog Ser 281:207-216

> Mills KL, Laidig T, Ralston S, Sydeman WJ (2007) Diets of top predators indicate pelagic juvenile rockfish (Sebastes spp.) abundance in the California Current System. Fish Oceanogr 16:273-283

Palacios D, Bograd S, Mendelssohn R, Schwing FB (2004) Long-term and seasonal trends in stratification in the California Current, 1950-1993. J Geophys Res 109:C10016, doi:10.1029/2004JC002380

> Parmesan C (2006) Ecological and evolutionary responses to recent climate change. Annu Rev Ecol Evol Syst 37: $637-669$

> Parmesan C, Yohe G (2003) A globally coherent fingerprint of climate change impacts across natural systems. Nature 421:37-42

Parrish RH, Mallicoate D, Klingbeil R (1986) Age dependent fecundity, number of spawnings per year, sex ratio, and maturation stages in northern anchovy, Engraulis mordax. Fish Bull (Wash DC) 84:503-517

> Pennington JT, Chavez FP (2000) Seasonal fluctuations of temperature, salinity, nitrate, chlorophyll and primary production at station H3/M1 over 1989-1996 in Monterey Bay, California. Deep-Sea Res II 47:947-973

> Perrins CM (1970) The timing of birds' breeding seasons. Ibis 112:242-255

$>$ Reed TE, Wanless S, Harris MP, Frederiksen M, Kruuk LEB, Cunningham EJA (2006) Responding to environmental change: plastic responses vary little in a synchronous breeder. Proc R Soc Lond B Biol Sci 273:2713-2719

Reed TE, Warzybok P, Wilson AJ, Bradley RW, Wanless S, Sydeman WJ (2009) Timing is everything: flexible phenology and shifting selection in a colonial seabird. J Anim Ecol 78:376-387

Ressler PH, Holmes JA, Fleischer GW, Thomas RE, Cooke KC (2007) Pacific hake, Merluccius productus, autecology: a timely review. Mar Fish Rev 69:1-24

- Richardson AJ, Poloczanska ES (2008) Ocean science: underresourced, under threat. Science 320:1294-1295

Root TL, Price JT, Hall KR, Schneider SH, Rosenzweig C, Pounds JA (2003) Fingerprints of global warming on wild animals and plants. Nature 421:57-60

> Roth J, Nur N, Warzybok P, Sydeman WJ (2008) Annual prey consumption of a dominant seabird, the common murre, in the California Current system. ICES J Mar Sci 65: 1046-1056

Schwing FB, Murphree T, Green PM (2002) The Northern Oscillation Index (NOI): a new climate index for the northeast Pacific. Prog Oceanogr 53:115-139 
Stenseth NC, Mysterud A (2002) Climate, changing phenology, and other life history traits: nonlinearity and matchmismatch to the environment. Proc Natl Acad Sci USA 99: 13379-13381

Stenseth NC, Mysterud A, Ottersen G, Hurrell JW, Chan KS, Lima M (2002) Ecological effects of climate fluctuations. Science 297:1292-1296

Sydeman WJ (1999) Climate change and the population biology of common murres and other seabirds of the California Current marine ecosystem. PhD thesis, University of California, Davis, CA

Sydeman WJ, Penniman JF, Penniman TM, Pyle P, Ainley DG (1991) Breeding performance in the western gull: effects of parental age, timing of breeding and year in relation to food availability. J Anim Ecol 60:135-149

Sydeman WJ, Hester MM, Thayer JA, Gress F, Martin P, Buffa J (2001) Climate change, reproductive performance and diet composition of marine birds in the southern California Current system, 1969-1997. Prog Oceanogr 49: 309-329

Sydeman WJ, Bradley RW, Warzybok P, Abraham CL and others (2006) Planktivorous auklet Ptychoramphus aleuticus responses to ocean climate, 2005: unusual atmospheric blocking? Geophys Res Lett 33:L22S09, doi:10.1029/2006 GL026736
Sydeman WJ, Abraham CL, Vernon Byrd G (2008) Seabirdsockeye salmon co-variation in the eastern Bering Sea: phenology as an ecosystem indicator and salmonid predictor? Deep-Sea Res II 55:1877-1882

Trenberth KE (2001) Climate variability and global warming. Science 293:48-49

Wells B, Field J, Thayer J, Grimes C and others (2008) Untangling the relationships among climate, prey and top predators in an ocean ecosystem. Mar Ecol Prog Ser 364: $15-29$

Wilkerson FP, Lassiter AM, Dugdale RC, Marchi A, Hogue VE (2006) The phytoplankton bloom response to wind events and upwelled nutrients during the CoOP WEST study. Deep-Sea Res II 53:3023-3048

Wolf S, Sydeman WJ, Hipfner J, Abraham CL, Tershy B, Croll D (2009) Rangewide reproductive consequences of ocean climate variability for the seabird, Cassin's Auklet. Ecology 90(3):742-753

Yen PPW, Sydeman WJ, Morgan KH, Whitney FA (2005) Top predator distribution and abundance across the eastern Gulf of Alaska: temporal variability and ocean habitat associations. Deep-Sea Res II 52:799-822

Z Zhang HM, Bates JJ, Reynolds RW (2006) Assessment of composite global sampling: sea surface wind speed. Geophys Res Lett 33:L17714, doi:10.1029/2006GL027086

Appendix 1. Ptychoramphus aleuticus and Uria aalge. Summary statistics calculated and used for analysis of Cassin's auklet and common murre egg-laying dates

\begin{tabular}{|c|c|c|c|c|c|c|c|}
\hline Year & Mean & Median & $\mathrm{N}$ & Max & Min & $\mathrm{SD}$ & Variance \\
\hline \multicolumn{8}{|c|}{ Cassin's auklet } \\
\hline 1972 & 100.38 & 97.5 & 64 & 135 & 75 & 12.12 & 147.12 \\
\hline 1973 & 98.13 & 96 & 62 & 124 & 90 & 7.29 & 53.22 \\
\hline 1974 & 86.78 & 85 & 65 & 122 & 69 & 9.33 & 87.14 \\
\hline 1975 & 94.69 & 91 & 70 & 131 & 77 & 11.91 & 141.89 \\
\hline 1976 & 89.75 & 90 & 73 & 122 & 78 & 7.23 & 52.32 \\
\hline 1977 & 105.35 & 105 & 71 & 133 & 93 & 7.28 & 53.11 \\
\hline 1978 & 113.87 & 112 & 77 & 143 & 103 & 7.60 & 57.82 \\
\hline 1979 & 90.59 & 90 & 75 & 112 & 78 & 5.53 & 30.62 \\
\hline 1980 & 113.12 & 114 & 77 & 128 & 101 & 5.05 & 25.57 \\
\hline 1981 & 98.94 & 99 & 80 & 120 & 88 & 7.67 & 58.86 \\
\hline 1982 & 97.41 & 95 & 80 & 130 & 71 & 10.54 & 111.18 \\
\hline 1983 & 152.35 & 155 & 37 & 162 & 148 & 3.81 & 14.56 \\
\hline 1984 & 102.00 & 102 & 77 & 127 & 87 & 8.39 & 70.39 \\
\hline 1985 & 94.46 & 91 & 78 & 146 & 81 & 11.90 & 141.75 \\
\hline 1986 & 108.38 & 106 & 42 & 141 & 96 & 7.17 & 51.50 \\
\hline 1987 & 98.43 & 96 & 39 & 121 & 86 & 7.24 & 52.46 \\
\hline 1988 & 87.06 & 85 & 17 & 95 & 80 & 3.56 & 12.68 \\
\hline 1989 & 82.83 & 81 & 41 & 131 & 66 & 14.60 & 213.44 \\
\hline 1990 & 97.50 & 96 & 40 & 121 & 81 & 8.33 & 69.48 \\
\hline 1991 & 99.03 & 96 & 40 & 146 & 81 & 15.73 & 247.56 \\
\hline 1992 & 164.65 & 167 & 17 & 172 & 157 & 3.58 & 12.86 \\
\hline 1993 & 124.38 & 121 & 37 & 161 & 116 & 10.00 & 100.07 \\
\hline 1994 & 107.22 & 101 & 37 & 146 & 96 & 11.80 & 139.45 \\
\hline 1995 & 126.97 & 126 & 31 & 161 & 121 & 8.50 & 72.36 \\
\hline 1996 & 132.42 & 132 & 36 & 157 & 117 & 8.22 & 67.67 \\
\hline 1997 & 99.59 & 96 & 39 & 146 & 86 & 12.61 & 159.14 \\
\hline 1998 & 157.67 & 156 & 15 & 166 & 151 & 4.49 & 20.23 \\
\hline 1999 & 91.63 & 86 & 32 & 121 & 71 & 13.18 & 173.79 \\
\hline 2000 & 101.18 & 98 & 33 & 123 & 93 & 6.59 & 43.46 \\
\hline
\end{tabular}


Appendix 1 (continued)

\begin{tabular}{|c|c|c|c|c|c|c|c|}
\hline Year & Mean & Median & $\mathrm{N}$ & Max & Min & $\mathrm{SD}$ & Variance \\
\hline 2001 & 96.88 & 91 & 40 & 151 & 76 & 15.72 & 247.29 \\
\hline 2002 & 83.50 & 81 & 36 & 106 & 71 & 8.49 & 72.14 \\
\hline 2003 & 101.53 & 101 & 38 & 126 & 91 & 6.75 & 45.66 \\
\hline 2004 & 107.36 & 104.5 & 42 & 142 & 97 & 8.51 & 72.43 \\
\hline 2005 & 124.08 & 126 & 13 & 126 & 121 & 2.53 & 6.41 \\
\hline 2006 & 106.16 & 106 & 32 & 111 & 101 & 2.97 & 8.84 \\
\hline \multicolumn{8}{|c|}{ Common murre } \\
\hline 1972 & 142.56 & 140 & 98 & 187 & 127 & 10.75 & 115.63 \\
\hline 1973 & 141.00 & 139 & 130 & 161 & 130 & 7.45 & 55.59 \\
\hline 1974 & 138.32 & 137 & 139 & 158 & 128 & 6.45 & 41.65 \\
\hline 1975 & 138.17 & 136 & 137 & 162 & 130 & 6.55 & 42.99 \\
\hline 1976 & 137.04 & 135 & 164 & 168 & 126 & 7.47 & 55.94 \\
\hline 1977 & 137.69 & 137 & 108 & 160 & 126 & 7.42 & 55.07 \\
\hline 1978 & 144.90 & 144 & 114 & 162 & 136 & 4.29 & 18.42 \\
\hline 1979 & 129.20 & 130 & 135 & 161 & 116 & 5.47 & 29.99 \\
\hline 1980 & 134.60 & 134 & 138 & 152 & 126 & 4.97 & 24.78 \\
\hline 1981 & 128.55 & 128 & 135 & 160 & 117 & 6.25 & 39.17 \\
\hline 1982 & 133.82 & 134 & 70 & 156 & 125 & 5.94 & 35.36 \\
\hline 1983 & 161.08 & 162 & 45 & 181 & 143 & 8.70 & 75.76 \\
\hline 1984 & 134.69 & 132 & 128 & 184 & 121 & 10.79 & 116.47 \\
\hline 1985 & 129.27 & 128 & 110 & 166 & 118 & 7.62 & 58.14 \\
\hline 1986 & 135.63 & 135 & 111 & 160 & 127 & 5.74 & 33.01 \\
\hline 1987 & 130.17 & 130 & 114 & 156 & 118 & 5.06 & 25.66 \\
\hline 1988 & 119.86 & 119 & 119 & 158 & 107 & 6.24 & 38.98 \\
\hline 1989 & 123.01 & 121 & 126 & 162 & 107 & 9.35 & 87.42 \\
\hline 1990 & 123.19 & 122 & 135 & 158 & 108 & 7.92 & 62.76 \\
\hline 1991 & 126.65 & 126 & 125 & 146 & 110 & 4.60 & 21.22 \\
\hline 1992 & 149.34 & 146 & 93 & 182 & 133 & 9.33 & 87.14 \\
\hline 1993 & 130.53 & 128 & 112 & 169 & 119 & 8.31 & 69.09 \\
\hline 1994 & 125.37 & 125 & 133 & 151 & 110 & 6.28 & 39.55 \\
\hline 1995 & 134.04 & 134 & 142 & 162 & 123 & 6.03 & 36.47 \\
\hline 1996 & 130.92 & 128 & 150 & 167 & 120 & 8.34 & 69.71 \\
\hline 1997 & 125.96 & 125 & 143 & 157 & 115 & 6.62 & 43.83 \\
\hline 1998 & 142.53 & 141 & 101 & 167 & 122 & 9.07 & 82.31 \\
\hline 1999 & 126.17 & 125 & 102 & 164 & 114 & 8.54 & 73.07 \\
\hline 2000 & 130.89 & 130 & 105 & 156 & 118 & 8.67 & 75.24 \\
\hline 2001 & 127.16 & 127 & 130 & 157 & 113 & 6.37 & 40.64 \\
\hline 2002 & 123.86 & 123 & 136 & 157 & 111 & 7.88 & 62.13 \\
\hline 2003 & 130.84 & 128 & 147 & 164 & 116 & 8.92 & 79.65 \\
\hline 2004 & 130.26 & 130 & 150 & 151 & 115 & 5.49 & 30.19 \\
\hline 2005 & 143.94 & 144 & 168 & 177 & 131 & 6.48 & 42.01 \\
\hline 2006 & 138.38 & 137 & 189 & 171 & 124 & 7.33 & 53.77 \\
\hline
\end{tabular}

